\title{
Circulating lipid peroxidation, plasma and erythrocyte antioxidant status in patients with rheumatoid arthritis
}

\author{
Palanisamy Pasupathi ${ }^{1}$, Mathiyalagan Deepa ${ }^{2}$, P. Rani ${ }^{3}$ and R. Ramesh Sankar ${ }^{4}$ \\ ${ }^{1}$ Institute of Laboratory Medicine, K.G. Hospital and Postgraduate Medical Institute, Coimbatore 641018 , \\ Tamil Nadu; ${ }^{2}$ Department of Biochemistry \& ${ }^{3}$ Gynecology, Raajam Hospital, Karruppur, Salem 636 012, Tamil \\ Nadu; ${ }^{4}$ Sai Bhrenthavan Homeo Clinic, Omalur, Salem 636 455, Tamil Nadu, India. \\ e-mail:drppasupathi@gmail.com
}

\begin{abstract}
The aim of the study was to investigate the levels of lipid peroxidation, and both plasma and erythrocyte antioxidant states in patients with rheumatoid arthritis. The population consisted of 60 subjects divided into two groups, 30 subjects had evidence of rheumatoid arthritis and age and sex matched healthy subjects were studied as controls. The level of plasma and erythrocyte thiobarbituric acid reactive substances (TBARS) was markedly increased in both the rheumatoid arthritis patients when compared to control subjects. The activities of plasma and erythrocyte antioxidants were significantly decreased in rheumatoid arthritis. C reactive protein, rheumatoid factor and antistreptolysin-O were significantly higher in rheumatoid arthritis patients than in healthy subjects. In conclusion, on the basis of enhanced lipid peroxidation in rheumatoid arthritis patients with concomitant failure of both the plasma, and erythrocyte antioxidants defense mechanism. These results are consistent with the underlying hypothesis that there is an imbalance between reactive oxygen species production and the antioxidant defense system in inflammatory rheumatoid arthritis disease.
\end{abstract}

\section{Introduction}

Rheumatoid arthritis is a chronic progressive autoimmune disorder characterized by symmetric erosive synovitis and sometimes shows multisystem involvement. The long-term outcome of this disease is characterized by significant morbidity, loss of functional capacity, and increased mortality. This disease affects about $1 \%$ of the general population worldwide ${ }^{1}$.

Reactive oxygen species (ROS) are clearly involved in the pathogenesis of various diseases, including rheumatoid arthritis. ROS have been implicated as mediators of tissue damage in patients with rheumatoid arthritis. The synovial fluid of the inflamed rheumatoid joint swarms with activated neutrophils, which produce large amounts of $\mathrm{ROS}^{2}$. ROS are formed in oxidative processes that normally occur at relatively low levels in all cells and tissues. Under normal conditions, a variety of antioxidant mechanisms serve to control this ROS production. In contrast, high doses and/or inadequate removal ROS result in oxidative stress, which may cause severe metabolic malfunctions and damage to biological macromolecules. Further, decomposition of peroxidized lipid yields a wide variety of end products, including malondialdehyde. Elevated levels of malondialdehyde have been observed in the serum (or plasma) and synovial fluid of rheumatoid arthritis patients ${ }^{3}$. In recent years, increasing attention has been given to the role of reactive oxygen metabolites in the pathogenesis of inflammatory disease such as rheumatoid arthritis. Increased activity of free radicals, the unstable molecules associated with cell damage, is theorized to underlie the mucosal injury commonly seen in the various inflammatory diseases ${ }^{4}$.

Several antioxidant systems have been reported which have different activities. Circulating human erythrocytes possess the ability to scavenge $\mathrm{O}_{2}{ }^{-}$ and $\mathrm{H}_{2} \mathrm{O}_{2}$ generated extracellularly by activated neutrophils, superoxide dismutase, catalase, and glutathione peroxidase-dependent mechanisms. Superoxide dismutase, the first line of defense against ROS, catalyzes the dismutation of the superoxide anion into hydrogen peroxide. Catalase 
can then transform hydrogen peroxide into $\mathrm{H}_{2} \mathrm{O}$ and $\mathrm{O}_{2}$. Glutathione peroxidase is a selenoprotein, which reduces lipidic or non-lipidic hydroperoxides as well as $\mathrm{H}_{2} \mathrm{O}_{2}$ while oxidizing glutathione ${ }^{5,6}$. Therefore, the present study was aimed at comparing lipid peroxidation indices [as thiobarbituric acid reactive substances (TBARS)] and plasma concentrations of various antioxidants in rheumatoid arthritis patients as well as inflammatory and biochemical parameters in patients with rheumatoid arthritis and healthy controls matched by age and sex.

\section{Materials and Methods}

Study population: The population consisted of 60 subjects divided into two groups, 30 subjects had evidence of rheumatoid arthritis patients (15 females, 15 males; mean age $40.4 \pm 8.3$ years). The other 30 subjects age and sex matched healthy subjects were studied as controls (15 females, 15 males; mean age $42.2 \pm 7.6$ years). The patients with rheumatoid arthritis were diagnosed by the diagnostic criteria of the American Rheumatism Association and those who had been receiving corticosteroid agents, gold preparations, and/or dpenicillamine for at least 3 months before the consultation were excluded from this study. However, patients who had been receiving ordinary dosages of non-steroidal anti-inflammatory drugs (NSAID) were not excluded as almost all the patients with rheumatoid arthritis had been undergoing NSAID treatment. None of the patients or controls was a smoker or consumed alcohol or had any other chronic disease. The Ethics Committee of the Medical Faculty approved the study plan, and all subjects volunteered for the trial.

Preparation of blood samples: Blood samples from the antecubital vein, using a monovette system of blood collection, were taken before breakfast for determining the blood parameters. One $\mathrm{ml}$ of anticoagulated blood containing sodium EDTA was used for hematological analysis. The remaining anticoagulated blood was separated into plasma by centrifugation for $10 \mathrm{~min}$ at $1,000 \mathrm{x} \mathrm{g}$ at $+4^{\circ} \mathrm{C}$. Two $\mathrm{ml}$ of serum was used for the detection of $\mathrm{C}$ reactive protein, rheumatoid factor and antistreptolysin-O. Plasma and serum samples were stored at $-30^{\circ} \mathrm{C}$. Plasma was stored for $<3$ months pending measurement of enzymic activity. The remaining plasma was used for immediate lipid peroxidation assays. Blood hematological and serum inflammatory markers were measured within 6 hours of blood collection.

Blood collection and erythrocyte lysate preparation: Blood samples were collected by venous puncture in heparinized tubes and the plasma was separated by centrifugation at 1,000x $\mathrm{g}$ for $15 \mathrm{~min}$. After centrifugation, the buffy coat was removed and the packed cells were washed three times with physiological saline. A known volume of the erythrocytes was lysed with hypotonic phosphate buffer ( $\mathrm{pH}$ 7.4). The hemolysate was separated by centrifugation at $2,500 \times \mathrm{g}$ for $15 \mathrm{~min}$ at $2{ }^{\circ} \mathrm{C}$.

Biochemical investigation: Fasting blood glucose and serum uric acid were determined using by fully automated clinical chemistry analyzer (Hitachi 912, Boehringer Mannheim, Germany). Red blood cell count, total white blood cell count, platelet count, total hemoglobin and ESR were determined using fully automated hematology analyzer (ABX Pentra XL 80, USA). C reactive protein, rheumatoid factor and ASO level was estimated using fully automated clinical chemistry analyzer (Architect C 8000, Abbott Diagnostics, Japan)

Estimation of lipid peroxidation: Lipid peroxides were estimated by measurement of TBARS in plasma by the method of $\mathrm{Yagi}^{7}$ and in erythrocytes by the method of Donnan ${ }^{8}$. The pink chromogen produced by the reaction of thiobarbituric acid with malondialdehyde, a secondary product of lipid peroxidation was estimated. Results were expressed as $\mathrm{nmol} / \mathrm{mL}$ for plasma and $\mathrm{pmol} / \mathrm{mg} \mathrm{Hb}$ for erythrocytes.

Assay of superoxide dismutase and catalase: Superoxide dismutase was assayed utilizing the technique of Kakkar et al. ${ }^{9}$ based on inhibition of the formation of nicotinamide adenine dinucleotide, phenazine methosulfate and amino blue tetrazolium formazan. A single unit of enzyme was expressed as $50 \%$ inhibition of nitroblue tetrazolium reduction $/ \mathrm{min} / \mathrm{mg} \mathrm{Hb}$. Catalase was assayed colorimetrically at $620 \mathrm{~nm}$ and expressed as $\mu \mathrm{mol}$ of $\mathrm{H}_{2} \mathrm{O}_{2}$ consumed/min/mg $\mathrm{Hb}$ as described by Sinha ${ }^{10}$. The reaction mixture $(1.5 \mathrm{~mL})$ contained $1.0 \mathrm{~mL}$ of $0.01 \mathrm{M} \mathrm{pH} \mathrm{7.0-phosphate} \mathrm{buffer,} 0.1 \mathrm{~mL}$ of hemolysate and $0.4 \mathrm{~mL}$ of $2 \mathrm{M} \mathrm{H}_{2} \mathrm{O}_{2}$. The reaction was stopped by the addition of $2.0 \mathrm{~mL}$ of dichromate-acetic acid reagent (5\%potassium dichromate and glacial acetic acid were mixed in $1: 3$ ratio).

Estimation of reduced glutathione: Reduced glutathione content was determined by the method of Ellman ${ }^{11}$. $1.0 \mathrm{~mL}$ of plasma was treated with 0.5 $\mathrm{mL}$ of Ellmans reagent (19.8 $\mathrm{mg}$ of 5,5'dithiobisnitro benzoic acid (DTNB) in $100 \mathrm{~mL}$ of $0.1 \%$ sodium nitrate) and $3.0 \mathrm{~mL}$ of phosphate buffer (0.2 M, pH 8.0). The absorbance was read at $412 \mathrm{~nm}$. Erythrocyte reduced glutathione content was determined with dithionitrobenzoic acid using the method described by Beutler and Kelley ${ }^{12}$. 
Reduced glutathion content was expressed as $\mathrm{mg} / \mathrm{dL}$.

Assay of glutathione peroxidase and glutathione reductase: Glutathione peroxidase activity was measured by the method described by Rotruck et al. ${ }^{13}$ with modifications. Briefly, reaction mixture contained $0.2 \mathrm{~mL}$ of $0.4 \mathrm{M}$ Tris- $\mathrm{HCl}$ buffer $\mathrm{pH} 7.0$, $0.1 \mathrm{~mL}$ of $10 \mathrm{mM}$ sodium azide, $0.2 \mathrm{~mL}$ of hemolysate, $0.2 \mathrm{~mL}$ glutathione and $0.1 \mathrm{~mL}$ of 0.2 $\mathrm{mM}$ hydrogen peroxide. The contents were incubated at $37^{\circ} \mathrm{C}$ for $10 \mathrm{~min}$. The reaction was arrested by $0.4 \mathrm{~mL}$ of $10 \% \mathrm{TCA}$, and centrifuged. The supernatant was assayed for glutathione content by using Ellmans reagent. Glutathione peroxidase activity was expressed as $\mu$ moles of reduced glutathione consumed $/ \mathrm{min} / \mathrm{g} \mathrm{Hb}$. Glutathione reductase activity was assayed using oxidized glutathione as a substrate according to the method described by Carlberg and Mannervic ${ }^{14}$. The method was based on the absorbance change at $340 \mathrm{~nm}$ due to oxidation/reduction of $\mathrm{NADPH} / \mathrm{NADP}^{+}$. Glutathione reductase activity was expressed as $\mu \mathrm{mol}$ of NADPH oxidized/hour/mL.

Assay of glutathione-S-transferase: Glutathione-Stransferase activity was determined spectrophotometrically by the method of Habig et $\mathrm{al}^{15}$. The reaction mixture $(3 \mathrm{~mL})$ contained $1.0 \mathrm{~mL}$ of $0.3 \mathrm{mM}$ phosphate buffer (pH 6.5), $0.1 \mathrm{~mL}$ of 30 $\mathrm{mM}$ 1-chloro-2, 4-dinitrobenzene (CDNB) and 1.7 $\mathrm{mL}$ of double distilled water. After preincubating the reaction mixture at $37^{\circ} \mathrm{C}$ for $5 \mathrm{~min}$, the reaction was started by the addition of $0.1 \mathrm{~mL}$ of hemolysate and $0.1 \mathrm{~mL}$ of glutathione as substrate. The absorbance was followed for $5 \mathrm{~min}$ at $340 \mathrm{~nm}$. Glutathione-S-transferase activity was expressed as $\mu \mathrm{mol}$ of CDNB-GSH conjugate formed $/ \mathrm{min} / \mathrm{mg}$ $\mathrm{Hb}$.

Statistical analysis: All data were expressed as mean \pm SD. The statistical significance was evaluated by the Student' $t$ ' test using Statistical Package for the Social Sciences (SPSS Cary, NC, USA) version 10.0.

\section{Results and Discussion}

The mean age limit was $40.4 \pm 8.3$ years in rheumatoid arthritis patients and $42.2 \pm 7.6$ years in healthy control subjects (Table I). The decreased body mass index (BMI) in rheumatoid arthritis patients $\left(23 \pm 2.2 \mathrm{~kg} / \mathrm{m}^{2}\right)$ when compared to control subjects $\left(26 \pm 2.1 \mathrm{~kg} / \mathrm{m}^{2}\right)$ was statistically significant. Systolic blood pressure was significantly high in patients groups as compared with controls.
The levels of $\mathrm{C}$ reactive protein, rheumatoid factor, ASO, total WBC count, hemoglobin, platelet count and ESR were significantly increased in rheumatoid arthritis patients (Table II). However, the levels of blood glucose fasting, uric acid and total RBC counts in rheumatoid arthritis patients compare with healthy subjects did not differ significantly.

Table I: Demographic characteristic of healthy subjects and rheumatoid arthritis patients

\begin{tabular}{lcc|}
\hline Parameter & $\begin{array}{c}\text { Healthy subjects } \\
(\mathrm{n}=30)\end{array}$ & $\begin{array}{c}\text { RA patients } \\
(\mathrm{n}=30)\end{array}$ \\
\hline Age $($ years $)$ & $42.2 \pm 7.6$ & $40.4 \pm 8.3^{*}$ \\
Sex- $(\mathrm{M} / \mathrm{F})$ & $15 / 15$ & $15 / 15$ \\
Body mass index $\left(\mathrm{kg} / \mathrm{m}^{2}\right)$ & $23 \pm 2.2$ & $26 \pm 2.1^{* *}$ \\
Smokers & 9 & 18 \\
Hypertension & 2 & 12 \\
\hline
\end{tabular}

Values are given as mean \pm S.D; RA patients compare with normal healthy subjects $(* \mathrm{p}<0.05, * * \mathrm{p}<0.001)$

Table II: Levels of parameters related to biochemical, inflammation and hematological parameters in normal healthy subjects and rheumatoid arthritis patients

\begin{tabular}{|c|c|c|}
\hline Parameter & $\begin{array}{l}\text { Healthy subjects } \\
\qquad(\mathrm{n}=30)\end{array}$ & $\begin{array}{l}\text { RA patients } \\
\quad(n=30)\end{array}$ \\
\hline Fasting glucose (mg/dL) & $101 \pm 9$ & $99 \pm 17^{\mathrm{NS}}$ \\
\hline Uric acid (mg/dL) & $4.44 \pm 0.96$ & $4.72 \pm 1.01^{\mathrm{NS}}$ \\
\hline $\mathrm{C}$ reactive protein $(\mathrm{mg} / \mathrm{L})$ & $3.13 \pm 1.41$ & $16.67 \pm 1.92 * *$ \\
\hline Rheumatoid factor (IU/mL) & $5.92 \pm 1.03$ & $11.3 \pm 3.10 * *$ \\
\hline $\operatorname{ASO}(\mathrm{IU} / \mathrm{mL})$ & $0.04 \pm 0.00$ & $102 \pm 59 * *$ \\
\hline Hemoglobin (g/dL) & $14.8 \pm 1.6$ & $10.0 \pm 1.3^{* *}$ \\
\hline $\mathrm{RBC}$ count $\left(\mathrm{Cells} / 10^{6} \mu \mathrm{L}\right)$ & $5.5 \pm 0.95$ & $5.6 \pm 0.31^{\mathrm{NS}}$ \\
\hline WBC count $\left(\right.$ Cells $\left./ 10^{6} \mu \mathrm{L}\right)$ & $7.8 \pm 2.0$ & $11.3 \pm 2.6^{* *}$ \\
\hline ESR (mm/hour) & $7 \pm 2$ & $52 \pm 12^{* *}$ \\
\hline Platelet count $\left(\mathrm{Cells} / 10^{3} \mu \mathrm{L}\right)$ & $270 \pm 67$ & $350 \pm 80^{*}$ \\
\hline
\end{tabular}

Lipid peroxidation indicated by TBARS level was significantly higher in both plasma and erythrocytes levels in patients with rheumatoid arthritis patients compared to normal healthy subjects (Table III). The significantly decreased in the levels of plasma and erythrocyte glutathione, glutathione reductase and $\mathrm{C}$ reactive protein in rheumatoid arthritis patients compare with normal healthy subjects was statistically significant. A significant decrease in the activities of superoxide dismutase, catalase, glutathione peroxidase and glutathione-S-transferase in erythrocyte lysate was seen in rheumatoid arthritis patients as compared to normal healthy subjects (Table IV). 
Table III: Levels of plasma and erythrocytes TBARS, reduced glutathione (GSH) and glutathione reductase (GSHR) levels in normal healthy subjects and rheumatoid arthritis (RA) patients

\begin{tabular}{|c|c|c|}
\hline Parameter & $\begin{array}{l}\text { Healthy sub- } \\
\text { jects }(n=30)\end{array}$ & $\begin{array}{l}\text { RA patients } \\
\qquad(\mathrm{n}=30)\end{array}$ \\
\hline Plasma TBARS (nmol /mL) & $2.31 \pm 0.21$ & $5.12 \pm 0.25^{*}$ \\
\hline Erythrocyte TBARS (pmole & & \\
\hline mg/Hb) & $3.02 \pm 0.41$ & $6.16 \pm 0.73^{*}$ \\
\hline Plasma GSH (mg/dL) & $30.13 \pm 1.37$ & $23.03 \pm 2.14 *$ \\
\hline Erythrocytes GSH $(\mu \mathrm{mol} g / \mathrm{Hb})$ & $4.71 \pm 1.78$ & $2.56 \pm 1.12^{*}$ \\
\hline Plasma GSHR (mg/dL) & $52.21 \pm 6.42$ & $40.43 \pm 5.11 *$ \\
\hline Erythrocytes GSHR (Umin/g/Hb) & $11.20 \pm 3.71$ & $5.15 \pm 2.37 *$ \\
\hline
\end{tabular}

Values are given as mean \pm S.D; RA patients compare with normal healthy subjects $(* \mathrm{p}<0.001)$

Table IV: Activities of erythrocyte superoxide dismutase (SOD), catalase (CAT), glutathione peroxidase (GPx) and glutathione-STransferase (GST) in control and rheumatoid arthritis (RA) patients

\begin{tabular}{l|c|c|}
\hline Parameter & $\begin{array}{c}\text { Healthy subjects } \\
(\mathrm{n}=30)\end{array}$ & $\begin{array}{c}\text { RA patients } \\
(\mathrm{n}=30)\end{array}$ \\
\hline $\mathrm{SOD}\left(\mathrm{Unit}^{\mathrm{A}} / \mathrm{mg} \mathrm{Hb}\right)$ & $3.71 \pm 0.41$ & $2.32 \pm 0.21^{*}$ \\
$\mathrm{CAT}\left(\mathrm{Unit}^{\mathrm{B}} / \mathrm{mg} \mathrm{Hb}\right)$ & $60.5 \pm 6.71$ & $4727 \pm 5.51^{*}$ \\
GPx $\left(\right.$ Unit $\left.^{\mathrm{C}} \mathrm{mg} / \mathrm{Hb}\right)$ & $7.35 \pm 1.39$ & $5.71 \pm 0.72 *$ \\
GST $\left(\right.$ Unit $\left.^{\mathrm{D}} \mathrm{mg} / \mathrm{Hb}\right)$ & $2.50 \pm 0.45$ & $1.10 \pm 0.37^{*}$ \\
\hline
\end{tabular}

Values are given as mean \pm S.D; RA patients compared with normal healthy subjects $\left({ }^{*} \mathrm{p}<0.001\right)$; A - One unit of activity was taken as the enzyme reaction, which gave $50 \%$ inhibition of NBT reduction in one min; $\mathrm{B}-\mu$ mole of $\mathrm{H}_{2} \mathrm{O}_{2}$ consumed/min; $\mathrm{C}-\mu \mathrm{g}$ of $\mathrm{GSH}$ consumed $/ \mathrm{min}$; D - $\mu$ moles of $\mathrm{CDNB}-\mathrm{GSH}$ conjugate formed/min

The results of the study indicate that the TBARS level in plasma and erythrocyte was higher in the patient group than in the control group. ROS and other oxidants have been shown to be formed even in the normal physiological process ${ }^{16,17}$. It is known that activated inflammatory cells lead to ROS production in rheumatoid arthritis a systemic autoimmune disease ${ }^{18}$. Increased ROS, in turn, increase lipid peroxidation products and cause tissue injury ${ }^{19}$. Oxidant stress constitutes a serious pathophysiological factor for a wide variety of connective tissue disorders such as rheumatoid arthritis. Pathogenic mechanism of chronic inflammation is associated with increased production of ROS and free radicals (superoxide anion and hydrogen peroxide). Elevated free radical generations in inflamed joints and impaired antioxidant system have been implicated in rheumatoid arthritis. In this study, rheumatoid arthritis is a chronic degenerative disease; oxidative stress (e.g. TBARS) was higher in patients with rheumatoid arthritis patients than in healthy subjects. Furthermore, there was a close relationship between oxidative stress and inflammation in patients with rheumatoid arthritis. In addition, activities of some plasma and erythrocyte antioxidant enzymes in the rheumatoid arthritis group were lower than in the healthy subjects $^{20}$.

Human synovial fluid contains little catalase, glutathione peroxidase, reduced glutathione and superoxide dismutase. Thus, the superoxide radicals and hydrogen peroxide generated by phagocytes in the inflamed rheumatoid joint would not be efficiently scavenged. Therefore, synovial fluid from the knee joints of human rheumatoid patients contains increased levels of TBARS, suggesting increased lipid peroxidation in vivo. The TBARS is transported from the synovial fluid to the blood by the blood circulation system. TBARS levels were found to be significantly elevated in the patients with rheumatoid arthritis compared to controls. Increased plasma and erythrocyte TBARS levels in patients with rheumatoid arthritis observed in this report and previously published reports and are indirect indicators of increased ROS production $^{21}$.

In our study, reduced glutathion, glutathione reductase levels, glutathione peroxidase and catalase activities in plasma were lower in the patient group than in control. The TBARS levels in plasma samples were higher in the patient group than in the control group. Plasma and erythrocytes may be important in regulating oxidant reactions in the surrounding medium, thereby preventing freeradical-mediated cytotoxicity. However, the relationship between erythrocyte superoxide dismutase and rheumatoid arthritis is not clear. Our result that the activity of erythrocyte superoxide dismutase is unaltered is in agreement with most studies. Erythrocyte and serum glutathione peroxidase activities in patients with rheumatoid arthritis are controversial; as some reports show decreased $^{22,23}$ while others show unaltered ${ }^{24}$ activity levels. Our results of erythrocyte glutathione peroxidase and catalase activities, similar to Kamanli et al. ${ }^{25}$ showed significantly lower levels in patients with rheumatoid arthritis than in the other two groups. The statistically significant decreases in plasma glutathione peroxidase and catalase activities between healthy subjects and rheumatoid arthritis patients may be due to the inactivation of the enzymes by $\mathrm{H}_{2} \mathrm{O}_{2}$ and suggest that these enzymes may play an important role in the rheumatic process and increased oxidative stress

$\mathrm{ASO}, \mathrm{C}$ reactive protein and rheumatoid factor are active components related to the phagocytic system of polymorphonuclear leucocytes. In the event of neutrophils and macrophages being stimulated by 
pathogens, cytokines or other inflammation mediators, complements ( $\mathrm{C} 3$ and $\mathrm{C} 4$ together with other mediators such as $\mathrm{ASO}, \mathrm{C}$ reactive protein and rheumatoid factor) are liberated from the granule into the cytoplasm and play an important part in destroying phagocytosed materials. Also, these cells are able to produce superoxide radicals and other oxidant species when activated by diverse stimuli. The values of lipid peroxidation, mediated by neutrophils, depend on the severity of the inflammatory status. It was found that $\mathrm{C}$ reactive protein and rheumatoid factor in patients with rheumatoid arthritis might be sensitive inflammation markers for reflecting the presence and activity of the disease. The present study showed that malondialdehyde and parameters related with inflammation such as $\mathrm{ASO}, \mathrm{C}$ reactive protein and ESR showed an increase in the patient group compared to the control group. Circulating human red blood cells posses the ability to scavenge ROS generated extracellularly by activated neutrophils. Hence, the RBC with decreased antioxidant levels is easily destroyed. The significantly decreased values of RBC and hemoglobin in the blood of rheumatoid arthritis patients observed in our study are supported by other workers who reported that increased ROS production is indicative of $\mathrm{RBC}$ destruction in patients with rheumatoid arthritis ${ }^{25}$.

This study indicate that the antioxidant defense system is compromised in patients with rheumatoid arthritis, as evidenced by increased TBARS concentrations (the most potent marker of oxidative stress) and decreased levels of both plasma and erythrocyte antioxidant enzymes. We have also demonstrated that ESR, a serologic marker of inflammation, shows a significant correlation to malondialdehyde levels in patients with rheumatoid arthritis. These significant correlations between ESR, antioxidant states and ESR vs. TBARS in rheumatoid arthritis patients may be useful in predicting disease activity. Parallel to our findings, Yildirim et al. ${ }^{26}$ recently reported that serum $\mathrm{C}$ reactive protein, among the various acute phase reactants, was the most useful biochemical marker for evaluating the disease activity of patients with rheumatoid arthritis.

In conclusion, on the basis of enhanced lipid peroxidation in rheumatoid arthritis patients with concomitant failure of both the plasma, and erythrocyte antioxidants defense mechanism. These results are consistent with the underlying hypothesis that there is an imbalance between ROS production and the antioxidant defense system in inflammatory rheumatoid arthritis disease. The potential role of increased lipid, protein and DNA oxidation and impaired antioxidant capacity as a result of inflammatory character of rheumatoid arthritis seems to be related to disease severity.

\section{References}

1. Sarban S, Kocyigit A, Yazar M, Isikan UE. Plasma total antioxidant capacity, lipid peroxidation, and erythrocyte antioxidant enzyme activities in patients with rheumatoid arthritis and osteoarthritis. Clin Biochem. 2005; 38: 981-86.

2. Kuloglu M, Atmaca M, Tezcan E, Ustundag B, Bulut S. Antioxidant enzyme and malondialdehyde levels in patients with panic disorder. Neuropsychobiology 2002; 46: $186-89$

3. Tuzun A, Erdil A, Inal V, Aydin A, Bagci S, Yesilova Z, Sayal A, Karaeren N, Dagalp K. Oxidative stress and antioxidant capacity in patients with inflammatory bowel disease. Clin Biochem. 2002; 35: 569-72.

4. Yyldyrym K, Karatay S, Gureser G, Kyzyltunç A, Uour $\mathrm{M}$, Penel K. Antioxidant enzymes capacity in patients with rheumatoid arthritis: The relationship with disease activity score. Romatizma Cilt. 2004; 19: 81-86.

5. Michiels C, Raes M, Toussaint O, Remacle J. Importance of Se-glutathione peroxidase, catalase, and $\mathrm{Cu} / \mathrm{Zn}$-SOD for cell survival against oxidative stress. Free Radic Biol Med. 1994; 17: 235-48.

6. Cimen MYB, Cimen OB, Kacmaz B, Ozturk HS, Yorgancioglu R, Durak I. Oxidant/antioxidant status of the erythrocytes form patients with rheumatoid arthritis. Clin Rheumatol. 2000; 19: 275-77.

7. Yagi K. Lipid peroxides and human diseases. Chem Phys Lipids 1978; 45: 337-51.

8. Donnan SK. The thiobarbituric acid test applied to tissues from rats treated in various ways. J Biol Chem. 1950; 182: 415-19.

9. Kakkar PS, Das B, Viswanathan PN. A modified spectrophotometric assay of superoxide dismutase. Indian J Biochem Biophys. 1984; 21: 130-32.

10. Sinha KA. Colorimetric assay of catalase. Anal Biochem. 1972; 47: 389-94.

11. Ellman GL. Tissue sulfhydryl groups. Arch. Biochem Biophys. 1959; 82: 70-77.

12. Beutler E, Kelley BM. The effect of sodium nitrate on red cell glutathione. Experientia 1963; 19: 96-97.

13. Rotruck JT, Pope AL, Ganther HE, Swanson AB, Hafeman DG, Hoekstra WG. Selenium: Biochemical roles as a component of glutathione peroxidase. Science 1973; 179: 588-90.

14. Carlberg I, Mannervik B. Glutathione reductase, In: Methods in enzymalogy. Meister A (ed). New York, Academic Press, 1985, pp 484-90.

15. Habig WH, Pabst MJ, Jakoby WB. Glutathione-Stransferases, the first enzymatic step in mercapturic acid formation. J Biol Chem. 1974; 249: 7130-39.

16. Abuja PM, Albertini R. Methods for monitoring oxidative stress, lipid peroxidation and oxidation 
resistance of lipoproteins. Clin Chim Acta. 2001; 306: 117.

17. Ghiselli A, Serafini M, Natella F, Scaccini C. Total antioxidant capacity as a tool to assess redox status: critical view and experimental data. Free Radic Biol Med. 2000; 29: 1106-14.

18. Fox DA. Etiology and pathogenesis of rheumatoid arthritis. In: Arthritis and allied conditions a textbook of rheumatology. Koopman WJ, Moreland LW (eds). $15^{\text {th }}$ ed. Philadelphia, Lippincot Williams and Wilkins, 2005, pp 1089-115.

19. Jasin HE. Mechanisms of tissue damage in rheumatoid arthritis. In: Arthritis and allied conditions a textbook of rheumatology. Koopman WJ, Moreland LW (eds). $15^{\text {th }}$ ed. Philadelphia, Lippincot Williams and Wilkins, 2005, pp 1141-64.

20. Ahmet I, Şahabettin S. Total antioxidant response and oxidative stress in patients with rheumatoid arthritis. Arastirma 2007; 21: 67-73.

21. Gambhir JK, Lali P, Jain AK. Correlation between blood antioxidant levels and lipid peroxidation in rheumatoid arthritis. Clin Biochem. 1997; 30: 351-55.
22. Taysi S, Polat F, Gul M, Sari RA, Bakan E. Lipid peroxidation, some extracellular antioxidants, and antioxidant enzymes in serum of patients with rheumatoid arthritis. Rheumatol Int. 2002; 21: 200-04.

23. Nivsarkar M. Improvement in circulating superoxide dismutase levels: Role of non-steroidal antiinflammatory drugs in rheumatoid arthritis. Biochem Biophys Res Commun. 2000; 270: 714-16.

24. Kerimova AA, Atalay M, Yusifov EY, Kuprin SP, Kerimov TM. Antioxidant enzymes; possible mechanism of gold compound treatment in rheumatoid arthritis. Pathophysiology 2000; 7: 209-13.

25. Kamanli A, Naziroglu M, Aydilek N, Hacievliyagil C. Plasma lipid peroxidation and antioxidant levels in patients with rheumatoid arthritis. Cell Biochem Funct. 2004; 22: 53-57.

26. Yildirim K, Karatay S, Melikoglu MA, Gureser G, Ugur $\mathrm{M}$, Senel K. Associations between acute phase reactant levels and disease activity score (DAS28) in patients with rheumatoid arthritis. Ann Clin Lab Sci. 2004; 34: 423-26. 